Journal of Social Sciences 7 (3): 428-435, 2011

ISSN 1549-3652

(C) 2011 Science Publications

\title{
An Analysis of Teaching Styles in Primary and Secondary School Teachers based on the Theory of Multiple Intelligences
}

\author{
${ }^{1}$ Tajularipin Sulaiman, ${ }^{1}$ Aminuddin Hassan and ${ }^{2}$ Hor Yen Yi \\ ${ }^{1}$ Faculty of Educational Studies, Universiti Putra Malaysia, \\ 43400 Serdang Selangor \\ ${ }^{2}$ Center of Foundation Studies and Extension Education, \\ Multimedia University Cyberjaya, Selangor, Malaysia
}

\begin{abstract}
Problem statement: The practice of contemporary teaching methods that looked into student diversity had started to dominant most classrooms. In recent years, teachers had adopted a multiple intelligences approach in teaching to meet the needs of a wider range of students. Objective of the present study was to determine the Multiple Intelligence (MI) profile and teaching styles of primary and secondary school teachers. The study also focused on identification of the difference in teaching styles adopted between primary and secondary school teachers. Approach: This study involved 310 randomly selected primary and secondary teachers had applied a descriptive design in which questionnaires were used for the purpose of data collection. Correlation based techniques were used to determine the relationship as well as the magnitude among multiple intelligences. Results: Research findings showed that significant differences were present in five MI profile (spatial, naturalistic, logic/mathematics, interpersonal and musical) with $\mathrm{t}=2.75,2.55,3.56,3.05$ and -2.32 respectively and three significant differences in the teaching strategies (naturalistic, musical and intrapersonal) with $\mathrm{t}=-2.58,-3.78$ and 2.70 respectively between secondary and primary school teachers. Conclusion: It can be concluded that both primary and secondary teachers had utilized the theory of Multiple Intelligence (MI) in their teaching approaches in today's classroom.
\end{abstract}

Key words: Multiple Intelligence (MI), teaching styles, contemporary teaching, student diversity

\section{INTRODUCTION}

The notion of style could be defined as a person's preferred way of using one's ability and its one of the contributing factor of the nature of differences between individuals in terms of ways in thinking, learning, teaching as well as carrying out duties or tasks (Sternberg and Grigorenko, 1997). The concept of style is always being associated and linked with the nature of individuality and is used to describe an individual quality, form, activity or behavior sustained over time (Rayner and Riding, 1997). The idea of style could exist in all areas and domains in the field of education, be it cognition, thinking, teaching and learning and it is undeniable that all these will influence the performance of students in both academic and non-academic settings (Rayner and Riding, 1997; Sternberg and Grigorenko, 1997).

According to Biggs (2001) Fan and Ye (2007), the term teaching styles was introduced around the 1970s when the role of styles in teaching and learning were increasingly drawing the attention of educators due to their significance in influencing the quality of teaching and learning process. Teaching styles emphasizes on teachers and their distinct individual approach to teaching (Evans et al., 2008). Based on Kulinna et al. (2000) in Evans et al. (2008). Aydin et al. (2010) did a study on pre-service teachers and identified some factors that affect teaching methods selected: their mentors, the topic taught, pedagogical knowledge, students' demands, personal characteristic, time, subject matter knowledge, material available, classroom management, own experience and courses taken. Bahar and Tangac (2009) found that teaching approaches is related to concepts associations in students' minds. Through an awareness of their preferred teaching styles, teacher will be able reflect and gain better insight into themselves and how their teaching styles could be modified, revised or complemented to improve their interaction with students. However, researchers in this field had work independently and developed their own set of indicators for identifying the different types of

Corresponding Author: Tajularipin Sulaiman, Faculty of Educational Studies, University Putra Malaysia,

43400 Serdang Selangor, Malaysia 


\section{J. Social Sci., 7 (3): 428-435, 2011}

teaching styles and had led to the various dimensions in measuring teaching styles (Evans et al., 2008).

Throughout the years, several researchers had examined the nature and scope of teaching styles adding to the set of literature and contributing to the advancement or growth in related fields (Fan and Ye, 2007). For example, Stensrud and Stensrud (1983) examined the teaching style preferences of 95 public school teachers between visual, auditory and kinesthetic teaching styles and findings showed that $84.2 \%$ of teachers preferred the visual style, while $80 \%$ stated that kinesthetic was their least preferred teaching styles. Another example would be a study conducted by Henson and Borthwick (1984), where they proposed a model for teaching styles that consisted of 6 approaches: task-oriented, cooperative-planner, childcentered, participant-centered, learning centered and emotionally exciting. These styles were found to be mutually inclusive where each style complements one another yielding an effective teaching style when collaborated in different manners. It is in consensus between all educators and researchers that a possessing an extended repertoire of teaching strategies and styles would be beneficial to both teachers themselves as well as students to cater to needs of individual students and reach out to a wider range of students.

Another concrete research example on teaching styles is conducted by Sternberg (1997) where he proposed seven teaching styles consisting of Type 1 and Type II styles (Type I: creativity-generating and complex; Type II: norm-favoring and simplistic) based on the theory of mental self-government proposed by Sternberg (1997), being compiled and functionalized through the Thinking Styles in Teaching Inventory. The seven styles in teaching consisted of (1) legislative style, (2) executive style, (3) judicial style, (4) local style, (5) global style, (6) liberal style and (7) conservative style. Based on literature, a variety of factors could affect the choice of teaching styles between educators or teachers. The factors may include educational experience, professional level, dedication to teaching, teachers' age, gender, subject areas (Evans, 2004), socio-cultural background and attitudes (Finn, 1999), as well as grades taught (Fan and Ye, 2007). According to a study by Egel (2009), he looked into the issue of teaching styles by examining the dimensions of primary school students' language learning styles and the ways in which these styles influence the teaching styles of teachers. Based on the findings of the study, private school teachers were better able to recognize the learning styles of students and adapt their teaching styles to accommodate the needs of students compared to public school teachers where classes in public schools are generally overcrowded.
In recent years, although a variety of teaching styles had been identified through different inventories proposed by researchers in different studies, the practice of contemporary teaching methods had started to dominant most classrooms. With the emergence of the contemporary teaching methods, teachers had taken an eclectic approach towards the 'traditional classroom' approach and the contemporary teaching methods. The principle of traditional teaching method which tends to classify learners as a homogeneous group where teachers 'transmit' knowledge to all the students in the classroom with a similar set of teaching method and by the end of the term, teachers expect all the students to excel in the standardized test being conducted, vary with the idea of contemporary teaching methods which emphasized on individual differences.

Educators in the last decade had hence faced with the issue of students not being able to meet the assessment criteria of standardized exams where standardized exam focuses solely on 'basic skills' which comprises of linguistic and logical-mathematical intelligences among students, overlooking other variations of intelligences that exist. But a divergent voice belonging to Harvard's cognitive researcher Gardner (1989) asserted that a redefinition of intelligence would enlarge the understanding of how children learn and become successful students (Jordan, 1996). Teachers struggle with finding ways to reach the diversity of individual learning styles and needs, hence teachers and educators had turned to the MI approach in teaching as a solution to teaching students with differences (Gouws, 2008; Klein, 2003; Reiff, 1997; Thompson and MacDougall, 2002) through eight varied pathways making MI a powerful tool that helps in achieving educational goals more effectively (and Hurry, 2000). This has led to the objective of the study that is to examine the differences that exist between the Multiple Intelligence profile as well as the teaching methods adopted between primary and secondary school teachers.

Personal characteristics of a teacher affects his/her teaching performance, effective teaching characteristics and teaching efficacy (Magno and Sembrano, 2008). According to the study conducted by $\mathrm{Wu}$ and Alrabah (2009), it was found that the Multiple Intelligence (MI) profile of an individual is very well related to their specific learning styles. Learning styles is closely associated to individual characteristics and preferences which reflect on the way a person perceive and interact with the environment, as well as respond and experience the learning process (Kazu, 2009). Individual will be able to learn and absorb knowledge better, increasing their successes when the content is delivered to them using teaching methods that emphasizes on their dominant intelligence or their 


\section{J. Social Sci., 7 (3): 428-435, 2011}

preferred learning methods (Felder, 1988; Kazu, 2009; Kelly and Tangney, 2004). In addition, individual could better relate themselves and actively make meaning out of the new knowledge that they were exposed to. It is evident that the primary and secondary curriculum is different in terms of the subject matters and the focus of intellectual development among students, the approaches that teachers adopt in teaching in both settings are important in determining the effectiveness of the learning process. Hence, with the idea in hand, the focus of this study is to identify the MI profile of secondary and primary school teachers and to compare their teaching styles based on the Multiple Intelligence theory proposed by Gardner (1999). Through this study the dominant types of intelligence of teachers in the primary and secondary schools through their teaching styles will be identified.

Implication of theory in education: Through the implementation of the Multiple Intelligence (MI) teaching approach in the classroom, teachers will indirectly decentralize the classroom, encouraging students to take a proactive role in their learning as well as transforming the teachers' role function from director to facilitator. Both teachers and students share the opportunity to develop their multiple intelligences as they learn together (Campbell, 1992). The use of multiple intelligences in instruction and response options provides a platform for students to have diverse and natural ways of learning and joining in the learning community in the classroom in addition, it effectively engages students in the learner-centered environment of the classroom and can foster personal autonomy, responsibility and empowerment (Gibson and Govendo, 1999).

Multiple Intelligences (MI) when applied to the classroom enable teachers to take note of various abilities and interest that students portray and also allow students to have a better learning connection and retention of the lesson (Mokhtar et al., 2008; Rettig, 2005). Other than that, teachers could be flexible in the presentation of materials which is being studied in order to create opportunities for all the students in class to use their different strengths (Currie, 2003) and encourages students to show more pride and enthusiasm in their work (Mokhtar et al., 2008). In addition, teaching children about multiple intelligences may enhance their developmental process, giving children more opportunities to feel confident about their abilities (Mattetal and Jordan, 1997).

The theory of Multiple Intelligence makes its greatest significance to education by encouraging teachers to expand their repertoire of teaching, tools and strategies, breaking free from the traditional linguistic and logical approaches and functions not only as a specific remedy to one-sidedness in teaching but also as an organizational tool that facilitates and complements existing educational pedagogy and to develop innovative teaching strategies (Ozdemir et al., 2006; Stanford, 2003). With a more developed repertoire of teaching methods, teachers could cater to a broader range of learners (Temur, 2007) with different learning strengths and weaknesses (Khan, 2009). Multiple intelligence theory could be used to enhance the teaching methods of teachers from all levels. Through multiple intelligence theory, teachers not only could focus on the strengths of students but also their weaknesses and to help students to develop these weaknesses (Greenhawk, 1997).

For early childhood education, teachers could address the MI theory and include an emphasis on toys and playthings, lesson planning, the use of centers and a focus on career education (Rettig, 2005). Teachers need to consider the types of toys and playthings available and how these relate to the multiple intelligences and then try to develop specific activities that incorporate the eight intelligences in a lesson plan. Centers then operates to organize activities involving the eight multiple intelligences around thematic units to be participated by students. Teachers could put focus on career education to students by linking the multiple intelligences to occupations through materials like books and field trip activities and role play (Rettig, 2005).

The multiple intelligence theory is being adapted in many teaching strategies by teachers. The multiple intelligence/storytelling approach is an example of the adaptation of teachers using MI theory to teach children at risk for learning difficulties because of its multisensory nature and its ability to pique the interest and incorporate the active participation of all children (Brand, 2006). Whereas, at the elementary level, Patricia Bolanos and her colleagues have used MI theory to design an entire public school in downtown Indianapolis, the children in Key School are given the opportunity to discover their areas of strength and to develop the full range of intelligences (Gardner and Hatch, 1989). Based on the article by Campbell (1992), MI theory is also being adapted to enhance the teaching methods of teachers through the implementation on The Four-step Model. The model is based on a four-step instructional sequence: the main lesson, centers sharing and reviewing and individual projects implementing the MI theory.

In many researches, it was found that both teachers and students agreed that the implementation of MI theory in their teaching and learning had a positive impact and students had gain self-confidence and motivation (Greenhawk, 1997; Haley, 2001; Kazu, 2009) throughout their learning process. Other than that, students had embraced the concept of MI theory in 


\section{J. Social Sci., 7 (3): 428-435, 2011}

education as it celebrated their diverse talents (Mattetal and Jordan, 1997). According to Heikkinen et al. (1985), teachers themselves too have a preferred method in perceiving and processing information and it is logical that teachers will communicate and teach their subject matter that is most compatible with their learning style. This can be further supported by the study conducted by Serin et al. (2009) which examines the relationship between teaching styles and MI profile of primary school teachers in Izmir and Lefkosa. Based on the findings, variables including the spatial/visual, naturalistic and interpersonal intelligences play a predictive role on the teaching strategies of teachers.

The MI classroom provides the environment for teachers to use varied teaching strategies, integrated curriculum and authentic assessment to provide creative and active learning that engages all students in the construction of their own meaning (Stanford, 2003). Teachers need to bear in mind that in teaching, in order to help students develop to their full potential, we need to employ the whole range of human capabilities to encourage and teach our students what they will need in order to become "all that they can be" in the world in which they live (Gibson and Govendo, 1999).

\section{MATERIALS AND METHODS}

Sample: The respondents in this study consisted of 310 randomly selected teachers who teach at secondary and primary schools. The sample for the research was randomly selected according to types of schools. Through sampling, a total of 310 teachers were selected where 154 teachers were from secondary schools and 156 teachers were from primary schools. The profile of the sample teachers are organized according to gender, age, experience in teaching and highest academic qualification as seen in Table 1.

Based on Table 1, from the total of 310 teachers in both secondary and primary schools, 67 (21.61\%) were male teachers and $243(78.39 \%)$ were female teachers. In terms of age, $100(32.26 \%)$ teachers were found to be less than 30 years of age, $126(40.65 \%)$ teachers were in the age group of 31 till $40,84(27.1 \%)$ teachers were in the age group of 41 till 50 and above. The teaching experiences of teachers were divided into 4 categories. A total of $115 \quad(37.10 \%)$ teachers experienced less than 5 years of teaching,57 (18.39\%) teachers had 5.1 till 10 years of teaching experience, 67 $(21.61 \%)$ teachers had 10.1 till 15 years of teaching experience and the number of teachers with more than 15 years of teaching experience were found to be 71 $(22.90 \%)$. For the profile of highest academic qualification, $8(2.59 \%)$ teachers had achieved master or PhD level, whereas $184(59.35 \%)$ teachers had achieved degree level. $118(38.06 \%)$ teachers were reported to have achieved diploma/ certificate level.

Instrument: This study applied a descriptive design. It has adopted the descriptive survey approach in which questionnaires are used for the purpose of data collection. Correlation based techniques are used to determine the relationship as well as the magnitude among the eight types of multiple intelligences profiles and learning styles.

The questionnaire consists of three parts, Part A, Part B and Part C. Part A of the questionnaire is made up of items to obtain respondent's demographic information, Part B of the questionnaire investigates the teachers' profile of eight Intelligences and Part C of the questionnaire investigates the teaching strategies based on multiple intelligences where the items were constructed based on the different types of instructional activities that were categorized according to the eight types of intelligences practiced by teachers in the classroom. Each variable consists of 6 items. All items are assessed using 5-point likert-scale instrument ranging from (1) strongly not agree (2) Not Agree (3) Less Agree (4)Agree (5)Strongly agree. The respondents were to answer all the items in the questionnaire by labeling their preference on each item using the 5-point likert-scale provided.

Table 1: Teachers' profile according to gender, age, experience in teaching and highest academic qualification

\begin{tabular}{|c|c|c|c|c|}
\hline & \multirow[b]{2}{*}{ Teachers' profile } & \multicolumn{2}{|l|}{ Number of teachers } & \multirow{2}{*}{$\begin{array}{l}\text { Total number of } \\
\text { teachers }\end{array}$} \\
\hline & & Secondary school & Primary school & \\
\hline \multirow[t]{2}{*}{ Gender } & Male & 37 & 30 & 67 \\
\hline & Female & 117 & 126 & 243 \\
\hline \multirow[t]{3}{*}{ Age } & Less than 30 & 47 & 53 & 100 \\
\hline & $31-40$ & 64 & 62 & 126 \\
\hline & $41-50$ and above & 43 & 41 & 84 \\
\hline \multirow[t]{4}{*}{ Experience in teaching } & Less than 5 years & 55 & 60 & 115 \\
\hline & 5.110 years & 37 & 20 & 57 \\
\hline & $10.1-15$ years & 26 & 41 & 67 \\
\hline & More than 15 years & 36 & 35 & 71 \\
\hline \multirow[t]{3}{*}{ Highest academic qualification } & Master/PhD & 6 & 2 & 8 \\
\hline & Degree & 139 & 45 & 184 \\
\hline & Diploma/Certificate & 9 & 109 & 118 \\
\hline Total & 154 & 156 & 310 & \\
\hline
\end{tabular}




\section{J. Social Sci., 7 (3): 428-435, 2011}

\section{RESULTS}

Based on Table 2, significant differences were present in five MI profile between secondary and primary school teachers as the value of $p<0.05$. The five MI profiles that are with significant difference between secondary and primary school teachers are spatial, naturalistic, logic/mathematics, interpersonal and musical. The differences of these five MI profiles between secondary and primary school teachers were indicated by the $\mathrm{t}$ values where $\mathrm{t}=2.75,2.55,3.56$, 3.05 and -2.32 respectively. For the case of Musical profile, the value of $t$ equals to -2.32 indicates that the primary school teachers were more inclined in the aspect of music compared to secondary school teachers.

Based on Table 3, there were three significant differences between the teaching strategies utilized by secondary and primary school teachers as the value of $p$ $<0.05$. Primary school teachers were found to utilize naturalistic and musical teaching strategies more compared with secondary school teachers indicated by the value of $\mathrm{t}=-2.58$ and -3.78 respectively.

Table 2:T-test and mean score for the MI profile of teachers in primary and secondary schools

\begin{tabular}{llllll}
\hline \multirow{2}{*}{ MI profile } & Type of & & & & \\
\hline Spatial & School & Mean & $\mathrm{t}$ & $\mathrm{df}$ & Sig (2-tailed) \\
& Primary & 16.199 & 2.75 & 291 & $0.006^{*}$ \\
Linguistics & Secondary & 17.487 & & & \\
& Primary & 16.795 & 0.74 & 308 & 0.462 \\
Naturalistic & Secondary & 17.136 & & & \\
& Primary & 16.942 & 2.55 & 308 & $0.011^{*}$ \\
Logic/Mathematics & Secondary & 18.442 & & & \\
& Primary & 17.833 & 3.56 & 308 & $0.000^{*}$ \\
Intrapersonal & Secondary & 19.461 & & & \\
& Primary & 22.647 & 0.88 & 308 & 0.382 \\
Interpersonal & Secondary & 23.136 & & & \\
& Primary & 21.301 & 3.05 & 308 & $0.002^{*}$ \\
Musical & Secondary & 22.526 & & & \\
\multirow{2}{*}{ Kinesthetic } & Primary & 17.064 & -2.32 & 308 & $0.021^{*}$ \\
& Secondary & 15.494 & & & \\
& Primary & 17.968 & -0.1 & 308 & 0.92 \\
\hline
\end{tabular}

*: Significant at the level of $\mathrm{p}<0.05$

Table 3: T-test and mean score for the MI teaching strategies of teachers in primary and secondary schools

\begin{tabular}{|c|c|c|c|c|c|}
\hline MI profile & $\begin{array}{l}\text { Type of } \\
\text { school }\end{array}$ & Mean & $\mathrm{t}$ & df & Sig (2-tailed) \\
\hline \multirow[t]{2}{*}{ Linguistics } & Primary & 17.872 & -0.09 & 307 & 0.925 \\
\hline & Secondary & 17.824 & & & \\
\hline \multirow[t]{2}{*}{ Logic/Mathematics } & Primary & 20.891 & 1.12 & 308 & 0.262 \\
\hline & Secondary & 21.474 & & & \\
\hline \multirow{2}{*}{ Kinesthetic } & Primary & 19.513 & -1.44 & 307 & 0.151 \\
\hline & Secondary & 18.882 & & & \\
\hline \multirow[t]{2}{*}{ Spatial } & Primary & 18.282 & 1.37 & 308 & 0.171 \\
\hline & Secondary & 18.987 & & & \\
\hline \multirow[t]{2}{*}{ Interpersonal } & Primary & 20.839 & 1.68 & 307 & 0.094 \\
\hline & Secondary & 21.844 & & & \\
\hline \multirow[t]{2}{*}{ Naturalistic } & Primary & 19.271 & -2.58 & 307 & $0.010^{*}$ \\
\hline & Secondary & 17.935 & & & \\
\hline \multirow[t]{2}{*}{ Intrapersonal } & Primary & 21.703 & 2.7 & 307 & $0.007 *$ \\
\hline & Secondary & 22.896 & & & \\
\hline \multirow[t]{2}{*}{ Musical } & Primary & 16.013 & -3.78 & 308 & $0.000^{*}$ \\
\hline & Secondary & 13.695 & & & \\
\hline
\end{tabular}

*: Significant at the level of $\mathrm{p}<0.05$
There was also significant difference in intrapersonal teaching strategies between secondary and primary school teachers where the strategy is more popular among secondary school teachers indicated by the value $t=2.70$ as the level of significant $p<0.05$.

\section{DISCUSSION}

The focus of the study is to identify the MI profile of teachers and the comparison of teaching styles based on the multiple intelligence theory among primary and secondary school teachers. In general, respondents involved in this study consist of female teachers below the age of 40 years old. Most of the respondents were experienced teachers who obtained a degree in the teaching profession. The findings of the study were very well proven as the teaching profession is dominated by female teachers. According to EPRD (2005), from the year 2001 till 2005, the percentage of female teachers were $65.15,65.93,66.72,67.31$ and $67.22 \%$ respectively. The increased in the numbers of teachers with a degree in teaching is the result of the Education ministry's effort in encouraging teachers to further upgrade themselves as well as the teaching profession. Till date, there is a total of 28,000 teachers in the world of Malaysia (EPRD, 2009).

Based on findings of the study, five different MI profiles were identified between primary and secondary school teachers. The MI profiles include Spatial intelligence, Naturalistic intelligence, Logicalmathematic intelligence, Interpersonal intelligence and Musical intelligence. Secondary school teachers were found to be more developed in Spatial and Logicalmathematic intelligence compared to primary school teachers. This is because most secondary school teachers who obtained a degree in teaching possessed a higher level of abstract thinking compared to primary school teachers. Other than that, secondary school teachers also possessed higher naturalistic intelligence compared to primary school teachers. Secondary school teachers were found to be better in interpersonal intelligence because interaction with students plays a vital role in the effectiveness of the teaching and learning process in secondary years. Primary school teachers were better in Musical intelligence mainly due to the emphasis of game and music classes in primary school.

In the aspect of teaching styles, three significant teaching styles were identified between primary and secondary school teachers. It was found that the teaching style of primary school teachers focused on the naturalistic approach of the environment outside the classroom compared to the teaching style of secondary 


\section{J. Social Sci., 7 (3): 428-435, 2011}

school teachers which focused on learning's inside the classroom. This finding result is also similar with the findings obtained from the study conducted by Serin $e t$ al. (2009), stating that primary school teachers who are naturalistically inclined tend to adopt the naturalistic approach in their teaching. In secondary schools, the teaching style of teachers emphasized mainly on interpersonal approach which involves activities like discussion, group work and students interaction. A study had been conducted by McCombs and Barton (1998), stating that in order to motivate secondary school students to learn, it is crucial to formulate meaningful adult and peer relationships, conduct learner-centered activities like dialogues, collaboration and session on expression of personal and collective views as well as being respectful towards students' unique abilities and talents. Hence, secondary school teachers had adopted an interpersonal approach in their teaching to enhance the development of secondary school students, motivating them to take an active role in their own learning. In addition, the findings of the study also found that primary school teachers are more musically inclined. Based on the study by Lum (2008), children are frequently exposed to musical sounds from their learning environment which includes school, home or playground and that primary school teachers are prone to incorporate their repertoire of musical knowledge into subject-matter teaching to help children get connected to the content leading to a better learning experience of primary school children.

\section{CONCLUSION}

Based on the findings of the research, it can be concluded that both primary and secondary teachers utilizes the theory of Multiple Intelligence (MI) in their teaching approaches. However, the types of intelligences emphasized by teachers through their teaching differ between secondary and primary school due to the influences of the varying emphasis of learning subjects in both primary and secondary school. Secondary school teachers emphasized more on interpersonal teaching styles as many learning activities conducted in school involves student-student and teacher-student interaction. Whereas primary school teachers focused more on musical teaching styles as many learning activities in primary schools are based on music and rhythms. Both secondary and primary school teachers realizes the effectiveness of adopting the MI theory in their teaching method and by organizing their lessons based on the theory, teachers are able to help students to learn new skills better and efficiently. Different teaching style may suit different optimal context (Sternberg, 1997) and a teacher with a larger set of teaching styles profile in their pockets has more options in their teaching and pushing them to move further up heightened their career in education. Teaching styles has always been directly associated to the learning styles of students, hence it is advisable for teachers to develop and be accustomed to different teaching styles in order to maximize their impact within the classroom (Fan and Ye, 2007; Kazu, 2009) bringing novelty and creativity into their classroom. Research in this area also has implications for personnels in the educational field in conducting teachers training or teacher education program as well as helping us to gain better understanding of the different needs of teachers with different teaching styles.

\section{REFERENCES}

Aydin, S., N. Boz and Y. Boz, 2010. Factors that are influential in pre-service chemistry teachers' choices of Instructional strategies in the context of methods of separation of mixtures: A case study. Asia-Pacific Educ. Res., 19: 251-270. http://ejournals.ph/index.php?journal=TAPER\&pa ge $=$ article \&op=download $\&$ path $\% 5 B \% 5 \mathrm{D}=1046 \& \mathrm{p}$ ath\%5B \% 5D=1106

Bahar, M. and E. Tongac, 2009. The effect of teaching approaches on the pattern of pupils' cognitive structure: Some evidence from the field. AsiaPacific Educ. Res., 18: 21-45. http://webcache.googleusercontent.com/search?q=c ache:GHx10c55JKgJ:www.ejournals.ph/index.php \%3Fjournal\%3DTAPER\%26page\%3Darticle\%26o p\%3DviewArticle\%26path\%255B\%255D\%3D102 $8+$ The+effect+of+teaching+approaches+on+the $+p$ attern+of+pupils\%E2\%80\%99+cognitive+structure :+Some+evidence+from+the+field \&cd=1\&hl=en \& $\mathrm{ct}=\mathrm{clnk} \& \mathrm{gl}=\mathrm{pk} \&$ source $=\mathrm{www} \cdot \mathrm{google} \cdot \mathrm{com} \cdot \mathrm{pk}$

Brand, S.T., 2006. Facilitating emergent literacy skills: A literature-based, multiple intelligence approach. J. Res. Childhood Educ., 21: 133-148. http://direct.bl.uk/bld/PlaceOrder.do?UIN=201166 869\&ETOC $=$ RN\&from $=$ searchengine

Campbell, B., 1992. Multiple intelligences in action. Childhood Educ., 68: 197-200. http://eric.ed.gov/ERICWebPortal/search/detailmin i.jsp?_nfpb=true\&_\&ERICExtSearch_SearchValue _0=EJ450533\&ERICExtSearch_SearchType_0=no \&accno=EJ450533\

Currie, K.L., 2003. Multiple intelligence theory and the ESL classroom-preliminary considerations. Federal University of Espírito Santo, Brasil. http://iteslj.org/Articles/Currie-MITheory.html 
Egel, I.P., 2009. English language learning and teaching styles in two Turkish primary schools. Soc. Behav. Personality, $\quad 37$ : 1117-1128. http://www.ingentaconnect.com/content/sbp/sbp/20 09/00000037/00000008/art00014

EPRD, 2005. Educational Planning and Research Division Quick Facts. Ministry of Education Malaysia.

Evans, C., 2004. Exploring the relationship between cognitive style and teaching style. Educ. Psychol., 24:

509-530. http://direct.bl.uk/bld/PlaceOrder.do?UIN=152237 273\&ETOC $=$ RN\& from $=$ searchengine

Evans, C., M.J. Harkins and J.D. Young, 2008. Exploring teaching styles and cognitive styles: evidence from school teachers in Canada. North, 10: http://www.mendeley.com/research/exploringteaching-styles-and-cognitive-styles-evidencefrom-school-teachers-in-canada/

Fan, W. and S. Ye 2007. Teaching styles among shanghai teachers in primary and secondary schools. Educ. Psychol., 27: 255-272. http://direct.bl.uk/bld/PlaceOrder.do?UIN=208909 $147 \&$ ETOC $=$ RN\& from $=$ searchengine

Felder, R.M. and L.K. Silverman, 1988. Learning and teaching styles in engineering education. J. Eng. Educ., 78: 674-681. DOI: 10.1109/FIE.2008.4720326

Finn, P.J., 1999. Literacy with an Attitude. SUNY Press, Albany, ISBN: 0791442861, pp: 243.

Gardner, H. and T. Hatch 1989. Educational implications of the theory of multiple intelligences. Educ. Res., 18: 4-10. DOI: 10.3102/0013189X018008004

Gardner, H., 1983. Frames of Mind: The Theory of Multiple Intelligences. $2^{\text {nd }}$ Edn., Basic books, New York., ISBN: 0465025102, pp: 440

Gardner, H., 1999. Multiple Approaches to Understanding. In: Instructional-Design Theories and Models, Reigeluth, C.M., (Ed.)., Routledge, ISBN: 0805828591, London, 69-89.

Gibson, B.P. and B.L. Govendo, 1999. Encouraging constructive behavior in middle school classrooms a multiple-intelligences approach. Intervention School Clinic, 35: 16-21. DOI: 10.1177/105345129903500103

Gouws, F.E., 2008. Teaching and learning through multiple intelligences in the outcomes-based education classroom Afr. Educ. Rev., 4: 60-74. DOI: 10.1080/18146620701652705

Greenhawk, J., 1997. Multiple Intelligences Meet Standards. Educ. Leadership, 62-64. http://direct.bl.uk/bld/PlaceOrder.do?UIN=031438 $743 \&$ ETOC $=$ RN\&from $=$ searchengine
Haley, M.H., 2001. Understanding learner-centered instruction from the perspective of multiple intelligences. Foreign Language Annals, 34: 355367.

http://www.eric.ed.gov/ERICWebPortal/search/det ailmini.jsp?_nfpb=true\&_\&ERICExtSearch_Searc hValue_0=EJ639361\&ERICExtSearch_SearchTyp e_0 =no\&accno=EJ639361

Heikkinen, M., $1985 . \quad$ Learning Styles vs. Teaching Styles--Studying the Relationship. NASSP Bull., 69: 80-85. http://eric.ed.gov/ERICWebPortal/search/detailmin i.jsp?_nfpb=true\&_\&ERICExtSearch_SearchValue _0=EJ311744\&ERICExtSearch_SearchType_0=no $\&$ accno=EJ311744

Henson, K.T. and P. Borthwick, 1984. Matching styles: A historical look. Theory Practice, 23: 3-9. http://www.jstor.org/pss/1476732

Hopper, B. and P. Hurry, 2000. Learning the MI Way: The Effects on students' learning of using the theory of multiple intelligences. Pastoral Care Educ., 18: 26-32. DOI: 10.1111/1468-0122.00176

İbrahim Y. Kazu, 2009. The effect of learning styles on education and the teaching process. J. Soc. Sci., 5: 85-94. DOI:10.3844/jssp.2009.85.94 http://perweb.firat.edu.tr/personel/yayinlar/fua_35/ 35_59283.pdf

Jordan, S.E., 1996. Multiple intelligences: seven keys to opening closed minds. NASSP Bull., 80: 29-35. http://eric.ed.gov/ERICWebPortal/search/detailmin i.jsp?_nfpb=true\&_\&ERICExtSearch_SearchValue _0=EJ535652\&ERICExtSearch_SearchType_0=no \&accno=EJ535652

Kelly, D. and B. Tangney, 2004. Predicting learning characteristics in a multiple intelligence based tutoring system. Intell. Tutor. Syst., 3220: 9-30. DOI: 10.1007/978-3-540-30139-4_64

Klein, P.D., 2003. Rethinking the multiplicity of cognitive resources and curricular representations: Alternatives to 'learning styles' and 'multiple intelligences. J. Curriculum Stud., 35: 45-82. http://direct.bl.uk/bld/PlaceOrder.do?UIN=125675 979\&ETOC $=\mathrm{RN} \&$ from $=$ searchengine.

Lum, C.H., 2008. Beyond music lessons: subject teachers' use of music in the classroom. Res. Stud. Music Educ., 30: 139-158. DOI:10.1177/1321103X08097504

Magno, C. and J. Sembrano, 2008. The role of teacher efficacy and characteristics on teaching effectiveness, performance and use of learnercentered practices. Asia-Pacific Educ. Res., 16: 7390. http://www.scribd.com/doc/7789850/The-Roleof-Teacher-Efficacy-and-Characteristics-onTeaching-Effectiveness 
Mattetal, G. and C. Jordan, 1997. Attitudes toward a multiple intelligences curriculum. J. Educ. Res., 91: 115-122. doi:10.1080/00220679709597529

McCombs, B.L. and M.L. Barton, 1998. Motivating secondary school students to read their textbooks. NASSP Bull., 82: 24-33. DOI:10.1177/019263659808260006

Mokhtar, I.A., S. Majid and S. Foo, 2008. Teaching information literacy through learning styles The application of Gardner's multiple intelligences. J. Librarianship Inform. Sci., 40: 93-109. DOI:10.1177/0961000608089345

Ozdemir, P., S. Güneysu and C. Tekkaya, 2006. Enhancing learning through multiple intelligences. J. Biol. Educ., 40: 74-78. http://direct.bl.uk/bld/PlaceOrder.do?UIN=183784 119\&ETOC $=$ RN\&from $=$ searchengine

Rayner, S. and R.J. Riding, 1997. Towards a categorisation of cognitive styles and learning styles. Educ. Psychol., 17: 5-27. DOI: 10.1080/0144341970170101

Reiff, J.C., 1997. Multiple intelligences, culture and equitable learning. Childhood Educ., 73: 301-304. http://direct.bl.uk/bld/PlaceOrder.do?UIN=027907 702\&ETOC $=$ RN\& from $=$ searchengine

Rettig, M., 2005. Using the multiple intelligences to enhance instruction for young children and young children with disabilities. Early Childhood Educ. J., 32: 255-259. DOI:10.1007/S10643-004-0865-2

Serin, N.B., O. Serin, M.A. Yavuz and B. Muhammedzade, 2009. The relationship between the primary teachers' teaching strategies and their strengths in multiple intelligences (Their multiple intelligence types) (Sampling: Izmir and Lefkosa. Procedia Soc. Behav. Sci., 1: 708-712. DOI: 10.1016/J.SBSPRO.2009.01.124
Stanford, P., 2003. Multiple intelligence for every classroom. Intervent. School Clinic, 39: 80-85. DOI: 10.1177/10534512030390020301

Stensrud, R. and K. Stensrud, 1983. Teaching styles and learning styles of public school teachers. Perceptual Motor Skills, 56: 414-414. http://psycnet.apa.org/psycinfo/1983-33535-001

Sternberg, R.J. and E.L. Grigorenko, 1997. Are cognitive styles still in style. Am. Psychol., 52: 700-712. DOI: 10.1037/0003-066X.52.7.700

Sternberg, R.J., 1997. Thinking Styles. $1^{\text {st }}$ Edn., Cambridge University Press, Cambridge, ISBN: 0521553164, pp: 180.

Temur, O.D., 2007. The effects of teaching activities prepared according to the multiple intelligence theory on mathematics achievements and permanence of information learned by 4th grade students. Int. J. Environ. Sci. Educ., 2: 86-91. http://www.ijese.com/V2_N4_Dogan-Temur.pdf

Thompson, B.R. and G.D. MacDougall, 2002. Intelligent teaching: Using the Theory of Multiple Intelligences in the Inquiry Classroom. Sci. Teacher, 69: 44-48. http://direct.bl.uk/bld/PlaceOrder.do?UIN=114856 $319 \&$ ETOC $=$ RN\& from $=$ searchengine

Wu, S.H. and S. Alrabah, 2009. A cross-cultural study of Taiwanese and Kuwaiti EFL students' learning styles and multiple intelligences. Innovations Educ. Teach. Int. 46: 393-403. DOI: $10.1080 / 14703290903301826$

Zebun N. Khan, 2009. Differences between learning Styles in Professional Courses at University Level. J. Soc. Sci., 5: 236-238. DOI: 10.3844/JSSP.2009.236.238

http://www.doaj.org/doaj?func=abstract\&id=483312 